ks. Wojciech Góralski

Uniwersytet Kardynała Stefana Wyszyńskiego

iD $0000-0001-6548-4120$

$w$ Warszawie

DOI: $10.15290 /$ std.2019.05.03

\title{
STRUKTURY KOLEGIALNE W KOŚCIELE
}

\section{COLLEGIAL STRUCTURES IN THE CHURCH}

The phenomenon of collegiality in the Church, a particular fruit of the Second Vatican Council, can undoubtedly be regarded as one of the most significant signs of the times. The principle of collegial operation of the episcopate with its deep biblical roots, which has entered into the life of ecclesiastical community, remains the guarantee of universality and unity. Having its basis both in episcopal ordination and in hierarchical communion, the collegiality of bishops belongs to the structure of the Church, according to the will of its Founder.

Collegiality in an exact (effective) meaning, expressing the nature of the Church, is realized only in the College of Bishops with its head in the person of the Roman Pontiff. Like him, also Collegium Episcoporum (with his head) is an entity of supreme, full and universal power in the Church.

Apart from collegiality in the strict sense, in the Church there are forms of collegial action as an expression of collegiality in a broader sense (affective collegiality); they reveal the bishops' concern for other particular Churches and for the universal church. These forms include: the Synod of Bishops, particular synods, bishops' conferences, participation of bishops in the work of the renewed Roman Curia, visits of bishops ad limina and missionary cooperation.

Analysis and reflection on the problems of collegiality makes it possible to see the aspect of synodality, closely related to collegiality, as John Paul II pointed out in motu proprio Novo Millennio ineunte of January 6, 2001, encouraging to deepen this thread of discussion. It seems that the above-mentioned document of the International Theological Commission entitled La sinodalità nella vita e nella missione della Chiesa has become the answer to this suggestion. 
Key words: Church, synodality, the College of Bishops, effective collegiality, affective collegiality.

\section{Wstęp}

Do fundamentalnych zagadnień eklezjologii katolickiej, szczególnie aktualnych po Soborze Watykańskim II, należy niewątpliwie zasada kolegialności. Zarówno teologia, jak i prawo kanoniczne przez „kolegialność” sensu stricto (tzw. efektywną) rozumieją sposób sprawowania władzy w Kościele związany z posługą pasterską biskupów - tworzących permanentnie w jedności z Papieżem i pod jego przewodnictwem - Kolegium Biskupów. Jednocześnie przyjmuje się, że pomiędzy biskupami istnieje szczególna więź (communio episcoporum) i „poczucie kolegialności” (kolegialność sensu lato, czyli afektywna) ${ }^{1}$, znajdujące swój szczególny wyraz w określonych przez prawo formach działania kolegialnego. I tutaj fundamentem owej kolegialności jest więź i wspólnota sakramentalna istniejąca między członkami Kolegium Biskupów.

Natomiast przewidziane w prawie struktury służące pomocą biskupowi stojącemu na czele Kościoła partykularnego (składające się z przedstawicieli prezbiterium diecezjalnego i wiernych świeckich), jakkolwiek są organami kolegialnymi, to kolegialność ta ma zupełnie inny wymiar i znaczenie.

Kolegialność zatem, jak podkreśla Konstytucja dogmatyczna Lumen gentium Soboru Watykańskiego II, wynikająca z apostolskiego charakteru Kościoła, we właściwym znaczeniu, poprawnym teologicznie, ogranicza się wyłącznie do Episkopatu². Mamy tutaj do czynienia z wyjątkowym pojęciem teologicznym, kolegialność bowiem wyznacza charakter oraz naturę działania Episkopatu ${ }^{3}$. „Kolegialność biskupia, głosi motu proprio Apostolo suos Jana Pawła II o naturze teologicznej i prawnej konferencji Episkopatów z 21 maja 1998 roku, we

Zob. Jan Paweł II, Posynodalna Adhortacja apostolska „Pastores gregis” o biskupiej postudze Ewangelii Jezusa Chrystusa dlanadzieiświata (16.10.2003), [w:] Ustrójhierarchiczny Kościoła. Wybór źródeł, red. W. Kacprzyk, M. Sitarz, Lublin 2006, n. 8; Zob. także M. Faccani, Collegio e collegialità episcopali nel Sinodo 1969, Bologna 1991, s. 25.

2 Zob. Konstytucja dogmatyczna „Lumen gentium”, [w:] Sobór Watykański II. Konstytucje, Dekrety, Deklaracje. Tekst polsko-łacinski, wyd. 3, Pallotinum [b.r.w.], nn. 22 i 23.

3 R. Sobański, L'uso del concetto di collegialitànel contesto teologico deglienunciati ufficiali della Chiesa e le sue implicanze nel diritto canonico, „Concilium” 1 (1965), s. 63-64; T. Rozkrut, Instytucja Synodu Biskupów w Kościele posoborowym (studium historyczno-prawne), Tarnów 2010, s. 16-17. 
właściwym i ścisłym sensie jest [...] wyłącznym przywilejem całego Kolegium Biskupów, które jako podmiot teologiczny jest niepodzielne"4.

Kolegialność, owa - jak powie Jan Paweł II - „odkryta na nowo”, „uprzywilejowana forma posługi pasterskiej sprawowanej przez nich [biskupów - W.G.]

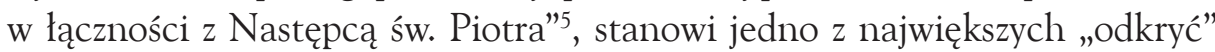
Vaticanum II ${ }^{6}$. Dobitnie wyeksplikowana w wymienionej Konstytucji o Kościele (nn. 22-23), a następnie w Posynodalnej Adhortacji apostolskiej Pastores gregis Jana Pawła II z 10 października 2003 roku , stanowi ogromny „«skok naprzód», a jednocześnie jest powrotem do tego, co pierwotne i początkowe, i co zostało zapisane na kartach Nowego Testamentu i w starochrześcijańskim Kościele".

Na struktury kolegialne w Kościele nowy strumień światła rzuca promulgowany przez Międzynarodową Komisję Teologiczną 2 marca 2018 roku (po uprzednim wyrażeniu pozytywnej opinii przez papieża Franciszka) dokument La sinodalità nella vita e nella missione della Chiesa (Synodalność w życiu i misji Kościoła $)^{9}$, w którym zasadę kolegialności porusza się w kontekście synodalności Kościoła.

Podczas gdy pojęcie synodalności, stwierdza się we wstępie tej enuncjacji, wiąże się z udziałem całego Ludu Bożego w życiu i misji Kościoła, to pojęcie kolegialności przywołuje znaczenie teologiczne i formę wykonywania posługi biskupów w służbie Kościoła partykularnego powierzonego trosce pasterskiej każdego i we wspólnocie między Kościołami partykularnymi; wykonywanie tej posługi dokonuje się w łonie jedynego i powszechnego Kościoła Chrystusowego, poprzez hierarchiczną wspólnotę Kolegium Biskupów z Biskupem Rzymu. Kolegialność więc, jest szczególną formą, w której synodalność kościelna wyraża się i urzeczywistnia poprzez posługę biskupów na poziomie wspólnoty między Kościołami partykularnymi w danym regionie i na poziomie wspólnoty

$4 \quad$ Jan Paweł II, List apostolski motu proprio „Apostolos suos” o naturze teologicznej i prawnej Konferencji Episkopatów ( 21.05.1998), [w:] Ustrój hierarchiczny Kościoła. Wybór źródet, red. W. Kacprzyk, M. Sitarz, Lublin 2006, n. 12.

5 List apostolski „Tertio Millennio adveniente” Ojca Świętego Jana Pawła II do biskupów, duchowieństwa $i$ wiernych w zwiazku z przygotowaniem Jubileuszu Roku 2000 (10.11.1994), Pallotinum 1995, n. 19.

6 J. Krasiński, Kolegialność władzy w Kościele przed Soborem Watykańskim II i przełom soborowy, „Studia Theologica Varsavensia” 1995, 33, nr 2, s. 5.

$7 \quad$ Jan Paweł II, Posynodalna Adhortacja apostolska „Pastores gregis”, (rozdział Kolegialny charakter postugi biskupiej, n. 8), Libreria Editrice Vaticana 2003.

8 J. Ratzinger, Duszpasterskie implikacje nauki o kolegialności biskupów, [w:] Concilium. Międzynarodowy Przegląd Teologiczny , t. 1, Poznań - Warszawa 1968, s. 66-68.

9 Commissione Teologica Internazionale, La sinodalità nella vita enella missione della Chiesa (02.03.2018),http://www.vatican.va/roman_curia/congregations/cfaith/cti_documents/ rrc_cti_20180302_sinodalita_it.html (dostęp: 18.05.2018). 
między wszystkimi Kościołami w Kościele powszechnym. Każdy autentyczny wyraz synodalności wymaga ze swojej natury wykonywania posługi kolegialnej biskupów ${ }^{10}$.

\section{Kolegium Biskupów i sposoby wykonywania przezeń władzy}

Eksponowanie przez wszystkich synoptyków faktu ustanowienia przez Jezusa Chrystusa zwartego zespołu Dwunastu Apostołów, występujących u Jego boku $^{11}$, wyposażonych w prerogatywy najwyższej władzy ${ }^{12}$, co w pragmatyce społecznej Izraela oznaczało powszechną władzę rządzenia, wskazuje jednoznacznie na biblijne korzenie kolegialności. Grono apostolskie stanowiło w pierwotnym Kościele wyraziście zarysowaną grupę hierarchiczną, która w sposób kolegialny kierowała życiem tej nowo założonej społeczności. Nie ulega również wątpliwości, że w pierwszych wiekach chrześcijaństwa odbywające się synody i sobory były jedną z podstawowych form współdziałania biskupów podejmowanego w poczuciu odpowiedzialności za cały Kościól, co stanowiło wyraz świadomości i pragmatyki kolegialnej ${ }^{13}$. „Biskupi w starożytnym Kościele, stwierdza J. Ratzinger, mieli wybitną, żywą świadomość swojej odpowiedzialności za cały Kościól, z czego wynikały różne formy wspólnej troski o jeden Kościół”14.

Ta wyraźna świadomość kolegialności z czasem uległa zatarciu i na wiele stuleci poszła w zapomnienie. Nic też dziwnego, że umieszczenie w porządku obrad Soboru Watykańskiego II problemu dotyczącego zasady kolegialności wywołało niemałe zaskoczenie, napotykając na liczne głosy sprzeciwu: obawiano się podważenia prymatu papieskiego, tak wyeksponowanego przez poprzedni Sobór. Dopiero po długich debatach prowadzonych w auli soborowej zgromadzeni tam hierarchowie uświadomili sobie, że relacja papież - biskupi w pełni odpowiada biblijnej relacji Piotr - Apostołowie. Kolegium Biskupów, jak stwierdza Konstytucja Lumen gentium, jest więc przedłużeniem Kolegium Apostolskiego „w nauczaniu i rządzeniu pasterskim”, a jego władza, podobnie jak władza papieża, pochodzi od Chrystusa ${ }^{15}$.

10 Tamże, Introduzione, n. 7.

$11 \quad$ Zob. Mt 3, 3-14; Mk 10, 1; Łk 6, 12.

12 Zob. Mt 18,18.

13 J. Krasiński, Kolegialność władzy w Kościele, s. 8-12.

14 J. Ratzinger, Duszpasterskie implikacje nauki o kolegialności biskupów, s. 56.

15 Konstytucja dogmatyczna „Lumen gentium”, n. 22; Zob. V.A. Berto, Collegio apostolico e „Collegio Episcopale”, Rovigo 1964, s. 1; Warto przytoczyć wypowiedź K. Wojtyły z 1972 roku: „Kolegialność Episkopatu pochodzi z ustanowienia samego Chrystusa i znajduje różnorakie potwierdzenie w życiu Kościoła przez stulecia” (OSynodzie Biskupów, „Tygodnik 
Z doktryny Vaticanum II w przedmiocie kolegialności wynika ponadto, że: 1) Kolegium Biskupów z jego głową (Biskupem Rzymu) - obok tejże głowy - jest podmiotem najwyższej i pełnej władzy w Kościele ${ }^{16}$; 2) do Kolegium wchodzi się przez przyjęcie święceń biskupich w łonie wspólnoty hierarchicznej, które to święcenia mają charakter sakralny i włączają biskupa w kolegialny, habitualny podmiot władzy nad całym Kościołem; 3) doktryna o kolegialności w niczym nie narusza prymatu Biskupa Rzymskiego ${ }^{17}$.

Kolegialna struktura Episkopatu ma na celu zagwarantowanie Kościołowi dwóch ważnych znamion: powszechności i jedności ${ }^{18}$, a charakter kolegialny Episkopatu należy do jego natury. Nic też dziwnego, że w rozumieniu eklezjologii katolickiej każdy biskup musi pełnić swoją posługę w jedności z Biskupem Rzymu - głową Kolegium; jednocześnie podziela on troskę całego Kolegium o wszystkie Kościoły ${ }^{19}$. W motu proprio Apostolos suos Jana Pawła II podkreśla, że „kolegialna jedność Episkopatu objawia naturę Kościoła [...]. Podobnie jak Kościół jest jeden i powszechny, tak i Episkopat jest jeden i niepodzielny”20.

Gdy chodzi o wykonywanie przez Kolegium Biskupów władzy w całym Kościele, to stosownie do stwierdzenia Konstytucji Lumen gentium (n. 22), w kan. $337 \mathrm{KPK}$ określono tutaj dwa sposoby: 1) sposób uroczysty: na soborze powszechnym $(\S 1) ; 2$ ) „przez jednomyślne działanie biskupów rozproszonych w świecie, które jako takie, zostało zapowiedziane lub dobrowolnie przyjęte przez Biskupa Rzymskiego, tak by się stało prawdziwym aktem kolegialnym" (§ 2). W obu przypadkach jest to władza zwyczajna i własna ${ }^{21}$. Dobieranie i promowanie jednego czy drugiego sposobu wykonywania władzy, stosownie do potrzeb Kościoła, należy do Papieża (kan. 337 §3 KPK).

Powszechny" 26 /1972/, nr 10, s. 1); Szerzej na temat relacji biskupi - prymat zob. J. Ratzinger, Episkopat und Primat, Freiburg im Br. - Basel 1963, s. 70-100.

Zob. E. Sztafrowski, Kolegialne działanie biskupów na tle Vaticanum II. Studium dogmatyczno-kanoniczne, Warszawa 1975, s. 95-99; J. Krzywda, Prymat papieski i Kolegium Biskupów w świetle nauki Vaticanum I $i$ II, Kraków 2008, s. 132-137.

Zob. Konstytucja dogmatyczna „Lumen gentium”, [w:] Sobór Watykański II. Konstytucje, Dekrety, Deklaracje. Tekst polsko-łaciński, Poznań 1967, nn. 22-23; Kan. 336 KPK deklaruje: „Kolegium Biskupów, którego głową jest Papież a członkami biskupi na mocy sakramentalnej konsekracji oraz hierarchicznej wspólnoty z głową Kolegium i członkami, w którym trwa nieprzerwanie ciało apostolskie, razem ze swoja głową, a nigdy bez niej, stanowi również podmiot najwyższej i pełnej władzy nad całym Kościołem”.

18 M. Lukoszek, Kolegium Biskupów a jedność Kościoła w nauczaniu Jana Pawła II. „Studia Warmińskie” 2010, 47, s. 217.

19 H. Seweryniak, Święty Kościót powszedni, Warszawa 1996, s. 107.

20 Jan Paweł II, List apostolski motu proprio „Apostolos suos”, Watykan 1998, n. 8.

21 J.R. Villar, Colegio Episcopal, [w:] Diccionario general de derecho canónico, t. 2, red. J. Otaduy, A. Viana, J. Sedano, Pamplona 2012, s. 235-236. 
Sposób uroczysty wykonywania władzy określają bliżej kann. 338-341 § 1 $\mathrm{KPK}$, wymieniając prerogatywy głowy Kolegium w odniesieniu do soboru powszechnego (zwołanie, określenie przedmiotu i porządku obrad, możliwość wezwania na sobór osób niebędących biskupami, wznowienie obrad po ich przerwaniu na skutek zawakowania Stolicy Apostolskiej albo rozwiązanie soboru, potwierdzenie i ogłoszenie dekretów soborowych).

Odnośnie do sposobu drugiego (nieuroczystego), a więc aktywności biskupów podjętej wskutek wezwania ich przez Papieża do kolegialnego działania bądź też takiego działania biskupów podjętego spontanicznie, to kan. 341 $\S 2$ KPK wymaga również potwierdzenia i ogłoszenia przez Papieża dekretów Kolegium Biskupów ${ }^{22}$.

Jak podkreśla się w dokumencie La sinodalità, sobór powszechny jest wydarzeniem nadzwyczajnym, bardziej dopełniającym i uroczystym, w którym wyrażają się kolegialność biskupia i synodalność kościelna na poziomie Kościoła powszechnego ${ }^{23}$.

\section{Formy działania kolegialnego biskupów jako wyraz kolegialności afektywnej}

W myśl Konstytucji soborowej Lumen gentium, kolegialna jedność „przejawia się również w stosunkach poszczególnych biskupów z Kościołami partykularnymi i Kościołem powszechnym" ${ }^{24}$. W nawiązaniu do tego stwierdzenia Adhortacja apostolska Pastores gregis podkreśla, że „poczucie kolegialności”, czyli kolegialność afektywna, z której wynika troska biskupów o inne Kościoły partykularne oraz o Kościół powszechny, „realizuje się i wyraża w różnym stopniu i na różne sposoby, także instytucjonalnie, jak np. Synod Biskupów, sobory partykularne, Konferencje Episkopatów, Kurię Rzymską, wizyty ad limina, współpracę misyjną"25.

\section{Synod Biskupów}

Gdy chodzi o Synod Biskupów - instytucję powołaną do życia motu proprio Apostolica sollicitudo Pawła VI z 15 września $1965 \mathrm{roku}^{26}$, dzieło Soboru Watykańskiego II, to - jak zauważa J. Krasiński - „jest prostym owocem 22 J. R. Villar, Colegio Episcopal, s. 236.

23 Commissione Teologica Internazionale, La sinodalità nella vita enella missione della Chiesa, n. 97.

24 Konstytucja dogmatyczna „Lumen gentium”, n. 23.

25 M. Lukoszek, Kolegium Biskupów a jedność Kościoła, s. 218.

26 Paulus VI, Motu proprio „Apostolica sollicitudo” (15.09.1965), AAS 57 (1965), s. 775-780. 
usankcjonowanej na Soborze Watykańskim II zasady kolegialności; jest praktyczną próbą realizacji tej kolegialności”27. Wymieniony Ojciec Święty akcentuje w powołanym dokumencie ścisłą łączność Papieża z biskupami oraz potrzebę współpracy wszystkich biskupów dla dobra Kościoła powszechnego. Będąc reprezentacją (w znaczeniu nieformalnym) całego Episkopatu (na poszczególnych zebraniach), Synod Biskupów ,jest znakiem, że wszyscy biskupi zespoleni hierarchicznie uczestniczą w trosce o cały Kościól”"2 . Jest habitualną formą wspólpracy o charakterze konsultacyjnym biskupów w wykonywaniu prymatu papieskiego jako głowy Kolegium, różniącą się od współpracy bezpośredniej Kurii Rzymskiej ${ }^{29}$. „Synod, powie Jan Paweł II (przytaczając kan. 333 $\S 2$ KPK), jest wydarzeniem, w którym w sposób szczególny staje się jasne, że następca Piotra w sprawowaniu swojego urzędu jest zawsze złączony komunią $z$ innymi biskupami i całym Kościołem" ${ }^{30}$.

Otwierając 30 września 1967 roku pierwsze zebranie generalne zwyczajne Synodu Biskupów Paweł VI podkreślił, iż chociaż Synod nie jest równy soborowi powszechnemu, to jednak stanowi jego obraz, odzwierciedlający jego ducha i metody, także dlatego, że reprezentuje całą hierarchię Kościoła katolickiego ${ }^{31}$. A 11 października 1969 roku, podczas drugiego zebrania generalnego nadzwyczajnego tegoż Synodu, poświęconego problematyce kolegialności, tenże Papież wskazał Synod jako praktyczny wyraz kolegialności biskupów i instytucję powołaną po to, aby wszyscy biskupi silniej ze sobą złączeni, bardziej istotnie uczestniczyli w rządach Kościoła powszechnego i byli zań solidarnie odpowiedzialni ${ }^{32}$. Z kolei Jan Paweł II, dziękując Bożej Opatrzności za dar Synodu Biskupów stwierdził, że „Synod jest dla Kościoła zawsze łaską szczególnego uobecnienia kolegialności Episkopatu całego Kościoła ${ }^{33}$.

27 J. Krasiński, Kolegialność władzy w Kościele, s. 22.

28 Dekret „Christus Dominus” Soboru Watykańskiego II, [w:] Sobór Watykański II. Konstytucje, Dekrety, Deklaracje. Tekst polsko-łaciński, Paris 1967, n. 5.

29 J. R. Villar, Colegio Episcopal, s. 237.

30 Jan Paweł II, Posynodalna Adhortacja apostolska „Pastores gregis”, n. 58.

31 Zob. G. Caprile, Sinodo dei Vescovi, Roma 1968, s. 101; J. Krasiński, Kolegialność władzy w Kościele, s. 23.

32 Paulus VI, Allocutio in Synodo Episcoporum (11.10.1969), [w:] Interventi e documentazione, Brescia 1992, s. 77-83.

33 List Ojca Świętego Jana Pawła II do kapłanów na Wielki Czwartek 1991 roku, „Miesięcznik Pasterski Płocki” 1991, 76, nr 6, s. 207. 
W obrębie norm KPK regulujących instytucję Synodu Biskupów (kann. $342-348)^{34}$ na szczególną uwagę zasługuje kan. 343, w którym stwierdza się, że

zadaniem Synodu Biskupów jest rozpatrywanie przedstawionych mu spraw i wysuwanie wniosków, nie zaś ich rozstrzyganie i wydawanie dekretów, chyba że w pewnych sprawach zostałby wyposażony w głos decydujący przez Biskupa Rzymskiego, do którego należy w takim przypadku zatwierdzenie decyzji Synodu.

Daleko idących zmian w strukturze i funkcjonowaniu Synodu Biskupów dokonał Franciszek w Konstytucji apostolskiej Episcopalis communio z 18 września 2018 roku $^{35}$. Największą nowością jest tutaj stałe usytuowanie Synodu Biskupów w ramach Kościoła konstytutywnie synodalnego: dokument ukazuje misję biskupów jako posługę na rzecz Ludu Bożego.

W części dyspozycyjnej Konstytucji znalazło się szereg postanowień stanowiących znaczące novum, m.in. poszerzono krąg osób uczestniczących w Zgromadzeniu Synodu, stworzono możliwość jego trwania w kilku odrębnych okresach, wskazano trzy fazy Synodu: przygotowania (na drodze szerokiej konsultacji Ludu Bożego w Kościołach partykularnych oraz odbywania zebrań przedsynodalnych), trwania i realizacji. Wprowadzono również normę dotyczącą przygotowania i promulgowania dokumentu końcowego Zgromadzenia Synodu. Wypracowany przez specjalną Komisję projekt powinien zostać przedłożony do zatwierdzenia członkom Zgromadzenia w celu uzyskania, jeśli to możliwe, „jednomyślności moralnej”. Po zatwierdzeniu przez członków Zgromadzenia dokument ma być przedstawiony Papieżowi, który decyduje o jego opublikowaniu. Jeśli zostanie przez niego wyraźnie zatwierdzony, dokument końcowy uczestniczy w Magisterium zwyczajnym Następcy Piotra. Jednocześnie dodano, iż gdyby Biskup Rzymski udzielił Zgromadzeniu głosu stanowczego (decydującego) stosownie do kan. $343 \mathrm{KPK}$, wówczas dokument końcowy uczestniczy w Magisterium zwyczajnym Następcy Piotra, przez niego zatwierdzony i promulgowany. W takim przypadku zostaje opublikowany z podpisem Biskupa Rzymskiego razem z podpisem członków Zgromadzenia.

Wypada dodać, że w debacie na temat Synodu Biskupów - w aspekcie kolegialności - pojawia się wątek dotyczący relacji tej instytucji do Kolegium Biskupów, a w szczególności charakteru i rodzaju kolegialności przypisanej Synodowi. Mając na uwadze względy praktyczne, a także przesłanki historyczne, niektórzy przedstawiciele doktryny teologicznej i kanonistycznej

34 Szerzej na temat regulacji kodeksowej zob. G.P. Milano, Il Sinodo dei Vescovi, Milano 1985, s. 251-371; E. Sztafrowski, Kolegialne działanie biskupów na tle Vaticanuum II, s. 117-172; T. Rozkrut, Instytucja Synodu Biskupów w Kościele posoborowym, s. 171-207.

35 Francesco, Costituzione Apostolica „Episcopalis communio”sul Sinodo del Vescovi (18.09.2018), http:/press.vatican/content/salastampa/it/bpllettino/pubblico/2018/09.18/0653/01389. html (dostęp 24.09.2018). 
sądzą, że jakkolwiek - jak to wyżej powiedziano - Synodus Episcoporum nie stanowi działania kolegialnego w sensie ścisłym (kolegialności efektywnej), to jednak, przy rosnącej liczbie biskupów, trudno byłoby dzisiaj zgromadzić cały Episkopat na soborze powszechnym; obecność wszystkich biskupów nie jest tutaj wymagana (zdaniem M. Coronaty wystarcza liczba niezbędna do reprezentowania Kościoła powszechnego). W związku z tym, a także mając na uwadze trudność w określeniu liczby biskupów, którzy mieliby reprezentować cały Episkopat oraz zważywszy, że w składzie Synodu Biskupów uwzględnia się reprezentatywność terytorialną, i że akt kolegialny nie musi być podejmowany bezpośrednio przez wszystkich stanowiących kolegium, niektórzy autorzy pytają, czy ewentualnie Synod Biskupów nie mógłby w przyszłości przejąć funkcji soboru powszechnego. Wielu odpowiada na to pytanie twierdząco ${ }^{36}$. Tak np. J. Krasiński, teolog, zauważa:

Synod Biskupów jako reprezentacja Episkopatu powszechnego, sprawniejszy od strony strukturalno-organizacyjnej, mógłby zostać podniesiony do działania ściśle kolegialnego i zastąpić sobór, który pozostałby ewenementem na kilka, lub więcej, ludzkich pokolenn ${ }^{37}$.

Edward Sztafrowski, kanonista, wyraża przekonanie o tym, że działalność biskupów na Synodzie może przybrać charakter aktu kolegialnego w sensie ścisłym: jako działanie stricte kolegialne biskupów rozproszonych w świecie, a „w przyszłości może przejąć funkcję soboru powszechnego" 38 .

Wydaje się, że tego rodzaju zapatrywania dopuszczające możliwość przejęcia funkcji soboru powszechnego przez Synod Biskupów nie rokują nadziei na ich spełnienie się: sobór powszechny - instytucja o wielowiekowej historii, w której urzeczywistnia się kolegialność efektywna, nie da się zastąpić jakąkolwiek formą reprezentacji Episkopatu światowego. To, że rośnie liczba biskupów, rozsianych na wszystkich kontynentach, i że nie wszyscy mogą przybywać na sobór, a także to, że daleko łatwiej jest zgromadzić uczestników danego zebrania Synodu Biskupów niż cały Episkopat, w żaden sposób nie może stanowić argumentu za przyznaniem Synodowi Biskupów rangi kolegialności efektywnej, właściwej jedynie Kolegium Biskupów. Należy pamiętać, że z punktu widzenia formalnoprawnego biskupi zgromadzeni na Synodzie Biskupów nie są reprezentacją Kolegium Biskupów (reprezentują jedynie swoje Kościoły partykularne i Konferencje Biskupów), można tu mówić wyłącznie o reprezentowaniu

36 Zob. W. Wójcik, Organizacja i procedura Synodu Biskupów, „Ateneum Kapłańskie” 60 (1968), s. 147; S. Soltyszewski, Synod Biskupów, „Prawo Kanoniczne” 1966, 9, nr 3-4, s. 297.

37 J. Krasiński, Kolegialność władzy w Kościele, s. 26,

38 E. Sztafrowski, Kolegialne działanie biskupów na tle Vaticanum II, s. 173. 
Kolegium w sensie moralnym ${ }^{39}$. Poza tym Synod Biskupów, w odróżnieniu od Kolegium, został powołany w celu niesienia pomocy Biskupowi Rzymskiemu (kan. $342 \mathrm{KPK})$.

Znacząca jest tutaj wypowiedź kard. J. Ratzingera z 1985 roku, w której przyszły Papież wskazuje, że najwyższa władza w Kościele, którą posiada Kolegium Biskupów zjednoczone z Biskupem Rzymskim, zgodnie z nauczaniem Vaticanum II, może być wykonywana jedynie na dwa sposoby (uroczyście na soborze powszechnym albo jako wspólne działanie biskupów rozproszonych w świecie). Dodał przy tym, że ani tradycja wschodnia ani zachodnia nie rozważa możliwości udzielenia niektórym biskupom, poprzez akt delegacji ze strony Kolegium, władzy uczestniczenia w kierowaniu Kościołem powszechnym, którą to władzę posiada Kolegium Biskupów wraz ze swoją głową w osobie Biskupa Rzymskiego $^{40}$. Nie bez znaczenia dla sprawy, o której mowa, jest także głos Jana Pawła II, który w przemówieniu do Kurii Rzymskiej z 21 grudnia 1990 roku stwierdził (po raz kolejny), że Synod Biskupów jest skutecznym wyrazem afektu kolegialnego, który należy rozumieć jako wspólną troskę o Kościół powszechny, przy zachowaniu świadomości, iż zachodzi istotna różnica między soborem powszechnym a Synodem Biskupów: kolegialność w sensie właściwym i ścisłym, oparta na prawie Bożym, przynależy jedynie do całego Collegium Episcoparum, a Synod Biskupów jest szczególnym wyrazem kolegialności biskupów z Papieżem ${ }^{41}$.

W przywołanym na wstępie dokumencie Międzynarodowej Komisji Teologicznej La Sinodalità stwierdza się, że w ciągu ponad pięćdziesięciu lat, jakie upłynęły od zakończenia Vaticanum II, znacznie dojrzała świadomość wspólnotowej natury Kościoła, o czym świadczy m.in. 14 zebrań generalnych Synodu Biskupów ${ }^{42}$.

39 Zob. J.I. Arrieta, Diritto dell'organizzazione ecclesiastica, Milano 1997, s. 267; M. Żurowski, Synodus Episcoporum in quantum „partes agens totius catholici Episcopatus”, „Periodica” 62 (1973), nr 3, s. 378; T. Rozkrut, Instytucja Synodu Biskupów w Kościele posoborowym, s. 242-243.; R. Sobański, L'uso del conceto di, ,collegialitā” nel contesto teologico deglienunciati ufficiali della Chiesa e le sue implicanze nel diritto canonico, „Concilium” 1990, 26, n. 4, s. 69.

40 J. Ratzinger, Scopi e metodi del Sinodo del Vescovi, [w:] Il Sinodo di Vescovi. Natura-metodo -prospettive, red. J. Tomko, Città del Vaticano 1985, s. 48.

41 Ioannes Paulus II, Ad Pates Cardinaes, Familiam domus Papae Romanamque Curiam, imminente Nativitate Domini Iesu Christi habita (21.12.1990), AAS 93 (1991), s. 744-745; T. Rozkrut, Instytucja Synodu Biskupów w Kościele posoborowym, s. 249-250.

42 Commissione Teologica Internazionale, La sinodalità nella vita enella missione della Chiesa, n. 41 . 


\section{Synody partykularne}

Inną formą aktywności biskupów są synody partykularne (prowincjalne i plenarne), objęte regulacją KPK (kann. 339-446) ${ }^{43}$. W motu proprio Apostolos suos Jan Paweł II stwierdza, że

kiedy biskupi na jakimś obszarze sprawują razem pewne funkcje pasterskie dla dobra swoich wiernych, to wspólne spełnianie posługi biskupiej staje się konkretną realizacją ducha kolegialnego (affectus collegialis), który jest „duszą współpracy między biskupami na szczeblu regionalnym, krajowym i międzynarodowym" ${ }^{44}$.

Jednocześnie Ojciec Święty zaznacza, że to wspólne działanie hierarchów jednakże nigdy nie nabiera charakteru kolegialnego właściwego dla aktów stanu biskupiego jako podmiotu najwyższej władzy nad całym Kościołem. Relacja między poszczególnymi biskupami a Kolegium Biskupów jest bowiem całkiem odmienna od ich relacji z instytucjami utworzonymi z myślą o opisanym wyżej wspólnym sprawowaniu pewnych funkcji pasterskich ${ }^{45}$.

W Adhortacji Pastores gregis Jan Paweł II uświadamia biskupom skupionym w prowincji kościelnej, że

konkretnym sposobem wspierania komunii pomiędzy biskupami i solidarności między Kościołami jest ożywienie starożytnej instytucji prowincji kościelnych, w których metropolici są narzędziem i znakiem zarówno braterstwa między biskupami, jak i ich komunii z Biskupem Rzymu ${ }^{46}$.

W tym samym dokumencie padają i takie słowa: „Na soborach partykularnych [...] wyrażona jest nie tylko komunia między biskupami, ale także komunia między Kościołami”7.

43 Zob. W. Góralski, Wprowadzenie do historii ustawodawstwa synodalnego w Polsce, Lublin 1991, s. 175-178 (synod plenarny); 159-161 (synod prowincjalny); Tenże, Instytucja synodu w Kodeksie Prawa Kanonicznego Jana Pawła II, „Prawo Kanoniczne” 1988, 31, nr 3-4, s. 35-45; W. Góralski, Synody partykularne, [w:] J. Dyduch. W. Góralski, E. Górecki, J. Krukowski, M. Sitarz, Komentarz do Kodeksu Prawa Kanonicznego, t. 2, cz. 1-2, Pallotinum 2005, s. 305-314; W. Góralski, Władza ustawodawcza Konferencji Episkopatu wedlug Kodeksu Prawa Kanonicznego Jana Pawta II, „Prawo Kanoniczne” 1989, 32, nr 1-2, s. $45-57$.

44 Są to słowa pochodzące z Relacji końcowej Synodu Biskupów z 1985 roku, „L’Osservatore Romano" (wyd. polskie) 1985, 6, nr 12, s. 6.

45 Jan Paweł II, List apostolski motu proprio „Apostolos suos”, n. 12.

46 Jan Paweł II, Posynodalna Adhortacja apostolska „Pastores gregis”, n. 62.

47 Tamże. 


\section{Konferencje Biskupów}

Szczególny wyraz kolegialności afektywnej urzeczywistnia się w Konferencjach Biskupów, które - jak głosi Konstytucja soborowa Lumen gentium - „mogą dziś wnieść różnorodny i owocny wkład do konkretnego urzeczywistnienia się pragnienia kolegialności” ${ }^{48}$. Instytucja ta, działająca de facto w wielu regionach kościelnych już od ponad stu lat, doczekała się formalnego uregulowania w KPK (kann. 447-459) ${ }^{49}$. W motu proprio Apostolos suos Jan Paweł II uznał Konferencję Biskupów za „konkretną formę realizacji ducha kolegialnego" ${ }^{50}$, a w Adhortacji Pastores gregis - za okazję do wzajemnej wymiany poglądów, konsultacji, współpracy dla dobra całego Kościoła ${ }^{51}$. Nie ulega wątpliwości, podkreśla E. Sztafrowski, autor monografii Kolegialne działanie biskupów na tle Vaticanum II, że

Konferencja Biskupia jest kolegialną formą działania biskupów, [...] jest nią w pewnym sensie bardziej niż Synod Biskupów, ponieważ do grona konferencji nie wchodzą nawet przedstawiciele zakonników, lecz jedynie ci, którzy pełnią pasterskie funkcje w diecezjach ${ }^{52}$.

Komentując motu proprio Apostolos suos, kard. A. Dulles zauważa, że Jan Paweł II często zachęca do wspólpracy między biskupami w ramach Konferencji Episkopatów czy z okazji innych spotkań na poziomie regionalnym. Dostrzega jednak pewne niebezpieczeństwa, które mogłyby wynikać z niewłaściwego rozumienia roli tej instytucji. Takim niebezpieczeństwem z jednej strony, mogłoby być tworzenie czegoś na kształt Kościoła narodowego, co godziłoby w jedność Kościoła powszechnego. Z drugiej strony, chodzi o obawę przejęcia przez daną konferencję kompetencji biskupów diecezjalnych, którzy są właściwymi pasterzami swoich Kościołów partykularnych wyposażonymi we władzę rządzenia. Zdaniem wymienionego teologa, Ojciec Święty, poprzez powołane wyżej motu proprio pragnął zapobiec takim zjawiskom ${ }^{53}$.

Współdziałanie biskupów skupionych w Konferencji Episkopatu pomaga im w rozwijaniu wartości właściwych jedności kolegialnej, do których należą m.in.

48 Konstytucja dogmatyczna „Lumen gentium”, n. 23.

49 Szerzej na temat regulacji kodeksowej zob. E. Sztafrowski, Konferencje Biskupie, Warszawa 1984, s. 319-323.

50 Jan Paweł II, List apostolski motu proprio „Apostolos suos”, n. 14.

51 Jan Paweł II, Posynodalna Adhortacja apostolska „Pastores gregis”, n. 63.

52 E. Sztafrowski, Kolegialne działanie biskupów na tle Vaticanum II, s. 234.

53 A. Dulles, Blask wiary. Wizja teologiczna Jana Pawta II, Kraków 2003, s. 114; Zob. także M. Lukoszek, Kolegium Biskupów a jedność Kościoła, s. 224. 
wzajemna znajomość, zrozumienie drugiego, szacunek dla sumienia innego człowieka, szczerość, lojalność, pokonywanie partykularyzmów i stronniczości54.

W działalności Konferencji Biskupów ujawnia się oczywiście kolegialność w znaczeniu szerszym ${ }^{55}$. W motu proprio Apostolos suos Jan Paweł II stwierdza: „Na płaszczyźnie zrzeszeń Kościołów partykularnych na określonych obszarach geograficznych (krajach, regionach, itp.) biskupi stojący na ich czele nie sprawują łącznie swej posługi pasterskiej poprzez akty kolegialne równe aktom Kolegium Biskupów" "N6. Natomiast w Dyrektorium Apostolorum successores Kongregacji ds. Biskupów z 22 lutego 2004 roku $^{57}$ stwierdza się, że różnorodne zgromadzenia biskupów prowincji czy regionu kościelnego, a przede wszystkim Konferencja Biskupów „są wyrazem kolegialnego wymiaru posługi biskupiej i jej koniecznego dostosowania do różnorodnych wspólnot ludzkich" ${ }^{58}$. W innym miejscu tego dokumentu zaznaczono, iż Konferencja Episkopatu, „która w ostatnich latach zyskała bardzo duże znaczenie, owocnie i na różne sposoby przyczynia się do realizowania i rozwoju kolegialności afektywnej [podkreśl. w tekście - W.G.] pomiędzy członkami tego samego Episkopatu" ${ }^{59}$.

W n. 4 Relacji końcowej Nadzwyczajnego Synodu Biskupów z 1985 roku przypomniano, że centralną ideą dokumentów Vaticanum II była eklezjologia komunii, która nadaje kolegialności podstawę sakramentalną. Dlatego też „dążność kolegialna”, dusza współpracy między biskupami, jest starsza niż kolegialność efektywna pojęta czysto prawniczo. Konferencje Episkopatu Synod zaliczył do działania kolegialnego w sensie szerokim, jako prawdziwy znak i narzędzie dążności kolegialnej. Uznał, że instytucji Konferencji Biskupów nie da się wyprowadzić bezpośrednio z teologicznej zasady kolegialności ${ }^{60}$.

Postanowienia Konferencji Biskupów, powzięte w zgodności z przepisami $\mathrm{KPK}$, nie są zatem aktami kolegialnymi, lecz kolektywnymi; swoją moc czerpią $z$ władzy poszczególnych biskupów wchodzących w skład konferencji ${ }^{61}$.

$54 \quad$ Tamże, s. 224.

55 Zob. P. Hemperek, Stanowisko prawne konferencji biskupów, „Prawo Kanoniczne” 1970, 13, nr 1-2, s. 45.

56 Jan Paweł II, List apostolski motu proprio „Apostolos suos”, n. 11.

57 Kongregacja Biskupów, Dyrektorium „Apostolorum successores” o pasterskiej postudze biskupów, [w:] Ustrój hierarchiczny Kościoła. Wybór źródet, red. W. Kacprzyk, M. Sitarz, Lublin 2006, Wprowadzenie.

58 Tamże, n. 22.

59 Tamże, n. 28.

60 H. Seweryniak, Święty Kościót powszedni, s. 239.

61 Tamże, s. 240. 
W dokumencie La sinodalità Międzynarodowej Komisji Teologicznej zaznaczono, iż do uaktywniania procesów synodalnych na poziomie krajowym, poza Konferencją Biskupów, mogą przyczyniać się również Zebrania kościelne (Convegni ecclesiali) popierane przez Konferencję (jak np. w Italii, gdzie odbywają się co dziesięć lat) ${ }^{62}$.

\section{Udział biskupów w pracach Kurii Rzymskiej}

Działanie kolegialne wyraża się następnie poprzez udział biskupów w pracach odnowionej Kurii Rzymskiej, która to instytucja świadczy na co dzień pomoc Biskupowi Rzymskiemu.

Już we wnioskach nadsyłanych do Stolicy Apostolskiej w związku z zapowiedzą Jana XXIII zwołania soboru powszechnego postulowano reformę Kurii Rzymskiej i dopuszczenie do niej biskupów diecezjalnych, co znalazło swój wyraz w debacie soborowej ${ }^{63}$. Odpowiadając na życzenie ojców soborowych, Paweł VI, w motu proprio Pro comperto sane z 6 sierpnia 1967 roku $^{64}$ postanowił wprowadzić do dykasterii kurialnych biskupów diecezjalnych, którzy mieli otrzymać pełnię praw członków tychże urzędów. Ojciec Święty potwierdził to w Konstytucji apostolskiej Regimini Ecclesiae universae z 15 sierpnia tego samego roku ${ }^{65}$.

Generalnej reformy Kurii Rzymskiej dokonał Jan Paweł II Konstytucją apostolską Pastor bonus z 28 czerwca 1988 roku $^{66}$. Całkowicie nowym elementem tego dokumentu było usytuowanie Kurii Rzymskiej w porządku eklezjologii wspólnoty i kolegialności (szczególnie w n. 9), w nawiązaniu do nauki Vaticanum II oraz do KPK na temat kolegialnego sposobu sprawowania władzy w Kościele ${ }^{67}$. Papież - Polak podkreśla, że Kuria Rzymska, pozostając w ścisłej więzi z najwyższym urzędem Piotra, przez zaangażowanie $w$ jej strukturach

62 Commissione Teologica Internazionale, La sinodalitànella vita enella missione della Chiesa, n. 90.

63 Zob. I. Gordon, De Curia Romana renovata, „Periodica” 1969, 58, s. 60-61; E. Sztafrowski, Kolegialne dziatanie biskupów na tle Vaticanum II, s. 241.

64 Paulus VI, Motu proprio „Pro comperto sane” (06.08.1967), AAS 59 (1967), s. 881-928.

65 Paulus VI, Constitutio apostolica „Regimini Ecclesiae universae” (15.06.1966), AAS 59 (1967), s. 841-934.

66 Ioannes Paulus II, Constitutio apostolica „Pastor bonus” (28.06.1988), AAS 80 (1988), s. $841-934$.

67 Zob. Dekret „Christus Dominus” Soboru Watykańskiego II, [w:] Sobór Watykański II. Konstytucje, Dekrety, Deklaracje. Tekst polsko-taciński, wyd. 3, Pallotinum [b.r.w.], n. 9. 
biskupów diecezjalnych, jeszcze ściślej zwiąże się, afektem miłości, z biskupami całego świata ${ }^{68}$.

Jako narzędzie w sprawowaniu władzy przez Papieża, stwierdza Jan Paweł II, Kuria Rzymska ma odniesienie do posługi biskupów i wszystkich Kościołów partykularnych. Z tej racji powinna się stawać coraz bardziej pomocna w nawiązywaniu wspólnoty między Papieżem i biskupami.

Kuria Rzymska, której dykasterie obejmują wielu biskupów, stwarza odpowiednie warunki do konkretnego zrealizowania „uczucia kolegialnego”, jakie powinno zaistnieć między biskupami oraz ich głową, tj. Biskupem Rzymskim. Skoro Kuria Rzymska ma obowiązek nawiązywania łączności ze wszystkimi Kościołami, to również pasterze Kościołów partykularnych, winni utrzymywać ścisłe kontakty z tą instytucją. Powinno to prowadzić do spotęgowania wspólnoty między wszystkimi ${ }^{69}$.

Dopuszczenie biskupów do członkostwa w dykasteriach Kurii Rzymskiej niewątpliwie powinno być rozpatrywane w kategoriach działania kolegialnego, oczywiście w znaczeniu szerszym, tj. kolegialności afektywnej.

\section{Wizyty biskupów ad limina}

W przekonaniu Jana Pawła II, wyrazem kolegialności - w znaczeniu afektywnym - są składane w Stolicy Apostolskiej co pięć lat przez biskupów wizyty ad limina Apostolorum; wyrażają one powszechność Kościoła, a także są „przejawem i zarazem środkiem komunii między biskupami a Katedrą Piotrową"70; są „przede wszystkim potwierdzeniem i umocnieniem kolegialności w ciele Kościoła, z której wynika jedność w różnorodności” ${ }^{11}$. „Z komunii wszystkich biskupów cum Petro et sub Petro, realizowanej w miłości, nadmienia Jan Paweł II, wypływa obowiązek współpracy wszystkich z następcą Piotra dla dobra całego Kościoła, a zatem dla każdego Kościoła partykularnego. Taki też bowiem jest cel wizyty ad limina ${ }^{72}$.

W Konstytucji apostolskiej Pastor bonus Ojciec Święty podkreśla, że wymienione wizyty mają szczególne znaczenie w życiu Kościoła, są bowiem „jakby szczytem relacji pasterzy każdego Kościoła partykularnego z Biskupem

\footnotetext{
68 Ioannes Paulus II, Constitutio apostolica „Pastor bonus”, n. 9.

69 E. Sztafrowski. Kuria Rzymska Jana Pawła II, „Prawo Kanoniczne” 1990, 33, nr 1-2, s. 37; J. Krzywda, Prymat papieski i Kolegium Biskupów, s. 274-276.

70 Zob. Jan Paweł II, Posynodalna Adhortacja apostolska „Pastores gregis”, n. 57.

71 Tamże.

72 Tamże.
} 
Rzymskim”; przyczyniają się „do wzmocnienia więzi hierarchicznej wspólnoty oraz jakby ukazują katolickość Kościoła i jedność Kolegium Biskupów”73.

Poprzez nawiedzanie poszczególnych dykasterii kurialnych, głosi powołana Konstytucja, dokonujące się podczas wizyt ad limina, zwiększa i pogłębia dialog między biskupami i Stolicą Apostolską, a ponadto „możliwa staje się wymiana informacji, a także przekazywanie wniosków i pożytecznych sugestii, dla większego dobra i rozwoju Kościołów, jak również dla zachowania wspólnoty dyscypliny kościelnej”74.

\section{Współpraca misyjna}

„Afektywna kolegialność sprawia, czytamy w Dyrektorium Apostolorum successores, że biskup nigdy nie jest sam - zawsze pozostaje w jedności z braćmi w biskupstwie i z tym, którego Pan wybrał na następcę Piotra"75. Stwierdzenie to odnosi się również do aktywności misyjnej biskupów: kolegialność zaznacza się w ich współpracy i w tym obszarze.

„Jako członkowie Kolegium, głosi Dekret o działalności misyjnej Kościoła Ad gentes divinitus Soboru Watykańskiego II, biskupi są konsekrowani nie tylko dla diecezji, ale i dla zbawienia wszystkich ludzi" "6 , co Jan Paweł II przypomniał w Adhortacji Pastores gregis ${ }^{77}$. Wszystkie więc działania pasterskie biskupa powinny być naznaczone duchem misyjnym ${ }^{78}$.

Obowiązek głoszenia Ewangelii spoczywa na Kolegium Biskupów. „Troska o głoszenie Ewangelii na całym świecie należy do grona pasterzy", stanowi Konstytucja Lumen gentium Soboru Watykańskiego II ${ }^{79}$. Biskupi, mimo iż zostały im powierzone konkretne Kościoły, to jednak troska o cały Kościół i odpowiedzialność duchowa za świat spoczywa na nich ${ }^{80}$.

\footnotetext{
73 Ioannes Paulus II, Constitutio apostolica „Pastor bonus”, art. 29.

74 Tamże, art. 30.

75 Kongregacja Biskupów, Dyrektorium „Apostolorum successores”, n. 12.

76 Dekret „Adgentes divinitus” Soboru Watykańskiego II, [w:] Sobór Watykański II. Konstytucje, Dekrety, Deklaracje. Tekst polsko-łacinski, wyd. 3, Pallotinum [b.r.w.], n. 38.

77 Jan Paweł II, Posynodalna Adhortacja apostolska „Pastores gregis”, n. 65.

78 Tamże.

79 Konstytucja dogmatyczna „Lumen gentium”, n. 23.

80 Zob. J. Górski, Obowiązek misyjny Ludu Bożego, „Śląskie Studia Historyczno-Teologiczne” 1986/87, 19/20, s. 170.
} 
W instrukcji Kongregacji ds. Biskupów Ecclesiae imago z 22 lutego 1973 roku $^{81}$ zaznaczono, iż „z największą gorliwością biskup współpracuje ze Stolicą Apostolską w ewangelizowaniu narodów" ${ }^{82}$. Kolegialność afektywna w tym zakresie wyraża się m.in. $\mathrm{w}$ tym, że biskup ma się starać, po porozumieniu ze Stolicą Apostolską i Konferencją Biskupów, by „zaradzić bezpośrednio potrzebom jakiegoś partykularnego Kościoła misyjnego, dostarczając tej diecezji ludzi i środków"83.

\section{Kolegialność na poziomie Kościoła partykularnego}

Kolegialność, aczkolwiek w znaczeniu jedynie analogicznym, urzeczywistnia się również w Kościołach partykularnych, „w których istnieje, i z których składa się jeden i jedyny Kościół katolicki" ${ }^{4}$.

Posiadając znamię powszechności, głosi Adhortacja Pastores gregis, Kościół Chrystusowy realizuje się w każdym Kościele partykularnym, otrzymując wszelkie środki naturalne i nadprzyrodzone do spełnienia misji, której wypełnianie w świecie Bóg powierzył Kościołowi ${ }^{85}$.

Elementami wewnętrznymi w każdym Kościele partykularnym są prymat Biskupa Rzymu i Kolegium Biskupów; , istnienie posługi Piotra wewnątrz każdego Kościoła partykularnego jest koniecznym wyrazem tego podstawowego wzajemnego przenikania się Kościoła powszechnego i Kościoła partykularnego" ${ }^{\text {"6 }}$.

W Kościele partykularnym istnieją struktury, które - jak to określa tytuł trzeci Dyrektorium Apostolorum successores - uczestniczą w funkcji pasterskiej biskupa. „Organiczna komunia kościelna i duchowość komunii, głosi powołany dokument, będą sprzyjały docenieniu przez biskupa struktur aktywnej wspólpracy działających zgodnie z prawem kanonicznym" 87 .

„Na szczycie wszystkich diecezjalnych struktur aktywnej współpracy w zarządzaniu diecezją przez biskupa, czytamy w tymże Dyrektorium, miejsce uprzywilejowane zajmuje synod diecezjalny”, który jest „wyrazem komunii

81 Kongregacja Biskupów, Instrukcja „Ecclesiae imago” na temat pasterskiej posługi biskupów (22.02.1973), [w:] Ustrój hierarchiczny Kościota. Wybór źródet, red. W. Kacprzyk, M. Sitarz, Lublin 2006, s. 404-516.

82 Tamże, n. 46.

83 Tamże.

84 Kan. 368 KPK.

85 Jan Paweł II, Posynodalna Adhortacja apostolska „Pastores gregis”, n. 56.

86 Tamże.

87 Kongregacja Biskupów, Dyrektorium „Apostolorum successores”, n. 166. 
hierarchicznej należącej do natury Kościoła”88, i który ma wymiar „aktu władzy biskupiej i przejawu komunii” ${ }^{99}$. „Podczas synodu diecezjalnego i z jego pośrednictwem biskup w uroczysty sposób wypełnia urząd i posługę kierowania swoją trzodą" ${ }^{\prime 0}$. Instytucję synodu diecezjalnego reguluje KPK (kann. 460-468) ${ }^{91}$.

Rolę synodu diecezjalnego podkreśla dokument Międzynarodowej Komisji Teologicznej La sinodalità, gdzie stwierdza się, że służy on odnowieniu i pogłębieniu poczucia odpowiedzialności kościelnej Ludu Bożego ${ }^{92}$.

Organem wspomagającym biskupa diecezjalnego na co dzień w jego zadaniach pasterskich jest Kuria Diecezjalna, składająca się $z$ instytucji i osób; jej zasadniczą strukturę określa KPK (kann. 469-494) ${ }^{93}$.

Ważną rolę w strukturach Kościoła partykularnego odgrywają rady będące organami konsultacyjnymi biskupa diecezjalnego: Rada Kapłańska (stanowiąca reprezentację prezbiterium diecezjalnego), o której w KPK (kann. 495-501)94; Kolegium Konsultorów (wyłonione spośród członków Rady Kapłańskiej przez biskupa diecezjalnego, w liczbie od sześciu do dwunastu), o którym w kan. $502 \mathrm{KPK}^{95}$; Rada Duszpasterska (organ fakultatywny, złożony z duchownych i wiernych świeckich, którego zadaniem jest badanie i rozważanie - pod zwierzchnictwem biskupa diecezjalnego - tego wszystkiego, co odnosi się do działalności duszpasterskiej), określona bliżej w KPK (kann. 511-514) ${ }^{96}$; Rada ds. Ekonomicznych, na czele której stoi sam biskup lub jego delegat (służy pomocą biskupowi diecezjalnemu w sprawach przygotowania bilansu dla diecezji, przyjmowania sprawozdań finansowych, itp.), której funkcjonowanie reguluje

88 Tamże, n. 167 .

89 Tamże, n. 169.

90 Tamże, n. 168.

91 Zob. W. Góralski, Struktury synodalne i kolegialne w Kościele partykularnym wedlug KPK Jana Pawta II, „Studia Płockie” 1986, 14, s. 55-57.

92 Commissione Teologica Internazionale, La sinodalitànella vita enella missione della Chiesa, n. 79 .

93 Zob. E. Sztafrowski, Podręcznik prawa kanonicznego, t. 2, Warszawa 1985, s. 151-172.

94 W. Góralski, Struktury synodalne i kolegialne w Kościele partykularnym, s. 57-61; E. Górecki, Rada Kapłańska, [w:] Struktury kolegialne w Kościele partykularnym. Materialy z ogólnopolskiej konferencji naukowej zorganizowanej przez Stowarzyszenie Kanonistów Polskich, Wydziat Nauk Prawnych TN KUL $i$ Wyższe Seminarium Duchowne w Tarnowie, red. J. Krukowski, T. Rozkrut, Tarnów 2004, s. 81-93.

Zob. W. Góralski, Struktury synodalne i kolegialne w Kościele partykularnym, s. 61-63; M. Sitarz, Kolegium Konsultorów w Kodeksie Prawa Kanonicznego z 1983 roku i w partykularnym prawie polskim, Lublin 1999.

96 Zob. W. Góralski, Struktury synodalne i kolegialne w Kościele partykularnym, s. 67-67; Tenże, Rada Duszpasterska - struktura i zadania, [w:] Struktury kolegialne w Kościele partykularnym. Materialy z ogólnopolskiej konferencji.., s. 109-126 
KPK (kann. 492-493) ${ }^{97}$; Kapituła Katedralna (powołana w celu sprawowania bardziej uroczystych czynności liturgicznych w kościele katedralnym), której działanie określa KPK (kann. 503-510) ${ }^{98}$.

Wypada wspomnieć, iż w myśl kan. 473 § 4 KPK, tam, „gdzie biskup uzna za wskazane dla bardziej odpowiedniego spotęgowania działalności pasterskiej, może ustanowić Radę Biskupią, złożoną z wikariuszy generalnych i wikariuszy biskupich". Wydaje się, że ów organ kolegialny powinien okazać się bardzo pożyteczny.

\section{Uwagi końcowe}

Zjawisko kolegialności w Kościele, szczególny owoc Soboru Watykańskiego II, można niewątpliwie uznać za jeden z bardziej znaczących znaków czasu. Zasada kolegialnego działania Episkopatu, która weszła na stałe w życie wspólnoty kościelnej, mająca swoje głębokie zakorzenienie biblijne, pozostaje rękojmią powszechności i jedności. Mając swoją podstawę zarówno w święceniach biskupich, jak i w komunii hierarchicznej, kolegialność biskupów należy do struktury Kościoła, zgodnie z wolą swojego Założyciela ${ }^{99}$.

Kolegialność w znaczeniu ścisłym (efektywna), wyrażająca naturę Kościoła, urzeczywistniana jest wyłącznie w Kolegium Biskupów z jego głową w osobie Biskupa Rzymskiego. Tak jak on, również Collegium Episcoporum (wraz ze swoją głową) stanowi podmiot najwyższej, pełnej i powszechnej władzy w Kościele ${ }^{100}$.

Poza kolegialnością w znaczeniu ścisłym istnieją w Kościele formy działania kolegialnego jako wyraz kolegialności w znaczeniu szerszym (kolegialność afektywna); ujawniają one troskę biskupów o inne Kościoły partykularne oraz o Kościół powszechny. Do form tych należą: Synod Biskupów, synody partykularne, konferencje biskupów, udział biskupów w pracach odnowionej Kurii Rzymskiej, wizyty biskupów ad limina oraz współpraca misyjna.

Analiza i refleksja nad problematyką kolegialności pozwala dostrzec aspekt synodalności, ściśle związany z kolegialnością, na co zwrócił uwagę Jan Paweł II w motu proprio Novo Millennio ineunte z 6 stycznia 2001 roku, zachęcając

\footnotetext{
97 Zob. tenże, Struktury synodalne i kolegialne w Kościele partykularnym, s. 67-68.

98 Tamże, s. 63-65; Obszerny wykaz bibliografii dotyczącej organów kolegialnych w Kościele partykularnym podaje M. Sitarz w pracy: Kompetencje organów kolegialnych w Kościele partykularnym w sprawowaniu wladzy wykonawczej wedtug Kodeksu Prawa Kanonicznego z 1983 roku, Lublin 2008, s. 267-297. 
do pogłębienia tego wątku ${ }^{101}$. Wydaje się, że odpowiedzią na tę sugestię stał się wspomniany wyżej dokument Międzynarodowej Komisji Teologicznej La sinodalità nella vita e nella missione della Chiesa.

Słowa kluczowe: Kościół, synodalność, Kolegium Biskupów, kolegialność efektywna, kolegialność afektywna.

\section{Bibliografia:}

1. Arrieta J.I., Diritto dell'organizzazione ecclesiastica, Milano 1997.

2. Berto V.A., Collegio apostolico e „Collegio Episcopale”, Rovigo 1964.

3. Caprile G., Sinodo dei Vescovi, Roma 1968.

4. Commissione Teologica Internazionale, La sinodalità nella vita e nella missione della Chiesa (02.03.2018),http:/www.vatican.va/roman_curia/congregations/cfaith/ cti_documents/rrc_cti_20180302_sinodalita_it.html (dostęp: 18.05.2018).

5. Dülles A., Blask wiary. Wizja teologiczna Jana Pawła II, Kraków 2003.

6. Faccani M., Collegio e collegialità episcopali nel Sinodo 1969, Bologna 1991.

7. Francesco, Costituzione Apostolica „Episcopalis communio”sul Sinodo del Vescovi (18.09.2018) http://press.vatican/content/salastampa/it/bpllettino/pubblico/2018/09.18/0653/01389.html (dostęp 24.09.2018).

8. Gordon I., De Curia Romana renovata, „Periodica” 1969, 58, s. 57-71.

9. Góralski W., Wprowadzenie do historii ustawodawstwa synodalnego w Polsce, Lublin 1991.

10. Góralski W., Instytucja synodu w Kodeksie Prawa Kanonicznego Jana Pawła II, „Prawo Kanoniczne" 1988, 31, nr 3-4, s. 35-45.

11. Góralski W., Struktury synodalne i kolegialne w Kościele partykularnym wedlug KPK Jana Pawła II, „Studia Płockie” 1986, 14, s. 55-57.

12. Góralski W., Synody partykularne, [w:] J. Dyduch. W. Góralski, E. Górecki, J. Krukowski, M. Sitarz, Komentarz do Kodeksu Prawa Kanonicznego, t. 2, cz. 1-2, Poznań 2005, s. 305-314.

13. Góralski W., Władza ustawodawcza Konferencji Episkopatu wedtug Kodeksu Prawa Kanonicznego Jana Pawla II, „Prawo Kanoniczne” 1989, 32, nr 1-2, s. 45-57.

14. Górecki E., Rada Kapłańska, [w:] Struktury kolegialne w Kościele partykularnym. Materiały z ogólnopolskiej konferencji naukowej zorganizowanej przez Stowarzyszenie Kanonistów Polskich, Wydział Nauk Prawnych TN KUL $i$ Wyższe Seminarium Duchowne w Tarnowie, red. J. Krukowski, T. Rozkrut, Tarnów 2004, s. 81-93.

15. Górski J., Obowiazek misyjny Ludu Bożego, „Śląskie Studia Historyczno-Teologiczne" 1986/87, 19/20, s. 168-179.

16. Hemperek P., Stanowisko prawne konferencji biskupów, „Prawo Kanoniczne” 1970, 13, nr 1-2, s. 21-48.

101 Jan Paweł II, List apostolski „Novo Millennio ineunte” do biskupów, duchowieństwa i wiernych na zakończenie Wielkiego Jubileuszu Roku 2000, Kraków 2001, n. 44. 
17. Ioannes Paulus II, Ad Pates Cardinaes, Familiam domus Papae Romanamque Curiam, imminente Nativitate Domini Iesu Christi habita (21.12.1990), AAS 93 (1991), s. 744-745.

18. Ioannes Paulus II, Constitutio apostolica „Pastor bonus” (28.06.1988), AAS 80 (1988), s. 841-934.

19. Jan Paweł II, List apostolski motu proprio „Apostolos suos” o naturze teologicznej i prawnej Konferencji Episkopatów (21.05.1998), [w:] Ustrój hierarchiczny Kościoła. Wybór źródet, red. W. Kacprzyk, M. Sitarz, Lublin 2006, s. 286-301.

20. Jan Paweł II, List apostolski „Novo Millennio ineunte” do biskupów, duchowieństwa $i$ wiernych na zakończenie Wielkiego Jubileuszu Roku 2000, Kraków 2001.

21. Jan Paweł II, Posynodalna Adhortacja apostolska „Pastores gregis” o biskupiej postudze Ewangelii Jezusa Chrystusa dla nadziei świata (16.10.2003), [w:] Ustrój hierarchiczny Kościoła. Wybór źródeł, red. W. Kacprzyk, M. Sitarz, Lublin 2006, s. 310-400.

22. Kongregacja Biskupów, Dyrektorium „Apostolorum successores” o pasterskiej postudze biskupów, [w:] Ustrój hierarchiczny Kościoła. Wybór źródeł, red. W. Kacprzyk, M. Sitarz, Lublin 2006, s. 517-711.

23. Kongregacja Biskupów, Instrukcja „Ecclesiae imago” na temat pasterskiej postugi biskupów (22.02.1973), [w:] Ustrój hierarchiczny Kościoła. Wybór źródet, red. W. Kacprzyk, M. Sitarz, Lublin 2006, s. 403-516.

24. Krasiński J., Kolegialność władzy w Kościele przed Soborem Watykańskim II i przełom soborowy, „Studia Theologica Varsaviensia” 1995, 33, nr 2, s. 5-30.

25. Krzywda J., Prymat papieski i Kolegium Biskupów w świetle nauki Vaticanum I i II, Kraków 2008.

26. List apostolski „Tertio Millennio adveniente” Ojca Świętego Jana Pawła II do biskupów, duchowieństwa $i$ wiernych w zwiąku z przygotowaniem Jubileuszu Roku 2000 (10.11.1994), Poznań 1995.

27. List Ojca Świętego Jana Pawła II do kapłanów na Wielki Czwartek 1991 roku, „Miesięcznik Pasterski Płocki” 1991, 76, nr 6, s. 206-209.

28. Lukoszek M., Kolegium Biskupów a jedność Kościoła w nauczaniu Jana Pawła II. „Studia Warmińskie” 2010, 47, s. 214-225.

29. Milano G.P, Il Sinodo dei Vescovi, Milano 1985.

30. Paulus VI, Allocutio in Synodo Episcoporum (11.10.1969), [w:] Interventi e documentazione, Brescia 1992, s. 77-83.

31. Paulus VI, Constitutio apostolica „Regimini Ecclesiae universae” (15.06.1966), AAS 59 (1967), s. 841-934.

32. Paulus VI, Motu proprio „Apostolica sollicitudo” (15.09.1965), AAS 57 (1965), s. 775-780.

33. Paulus VI, Motu proprio „Pro comperto sane” (06.08.1967), AAS 59 (1967), s. 881-914.

34. Ratzinger J., Duszpasterskie implikacje nauki o kolegialności biskupów, [w:] Concilium. Międzynarodowy Przegląd Teologiczny , t. 1, Poznań-Warszawa 1968, s. 65-78.

35. Ratzinger J., Episkopat und Primat, Freiburg im Br. - Basel 1963.

36. Ratzinger J., Scopi e metodi del Sinodo del Vescovi, [w:] Il Sinodo di Vescovi. Natura - metodo - prospettive, red. J. Tomko, Città del Vaticano 1985, s. 45-58. 
37. Rozkrut T., Instytucja Synodu Biskupów w Kościele posoborowym (studium historyczno-prawne), Tarnów 2010.

38. Seweryniak H., Święty Kościót powszedni, Warszawa 1996.

39. Sitarz M., Kolegium Konsultorów w Kodeksie Prawa Kanonicznego z 1983 roku $i$ w partykularnym prawie polskim, Lublin 1999.

40. Sitarz M., Kompetencje organów kolegialnych w Kościele partykularnym w sprawowaniu władzy wykonawczej wedlug Kodeksu Prawa Kanonicznego z 1983 roku, Lublin 2008.

41. Sobański R., L'uso del concetto di collegialità nel contesto teologico degli enunciati ufficiali della Chiesa e le sue implicanze nel diritto canonico, „Concilium” 1965, 1, s. 61-70.

42. Sobór Watykański II. Konstytucje, Dekrety, Deklaracje. Tekst polsko-łaciński, Poznań 1967.

43. Sołtyszewski S., Synod Biskupów, „Prawo Kanoniczne” 1966, 9, nr 3-4, s. 287-300.

44. Sztafrowski E., Kolegialne działanie biskupów na tle Vaticanum II. Studium dogmatyczno-kanoniczne, Warszawa 1975.

45. Sztafrowski E., Konferencje Biskupie, Warszawa 1984.

46. Sztafrowski E., Kuria Rzymska Jana Pawła II, „Prawo Kanoniczne” 1990, 33, nr 1-2, s. 21-81.

47. Sztafrowski E., Podręcznik prawa kanonicznego, t. 2, Warszawa 1985.

48. Villar J.R., Colegio Episcopal, [w:] Diccionario general de derecho canónico, t. 2, red. J. Otaduy, A. Viana, J. Sedano, Pamplona 2012, s. 235-236.

49. Wójcik W., Organizacja i procedura Synodu Biskupów, „Ateneum Kapłańskie” 1968, 60, s. 143-152,

50. Żurowski M., Synodus Episcoporum in quantum „partes agens totius catholici Episcopatus”, „Periodica” 1973, 62, nr 3, s. 375-386. 